\title{
УДК 339.564
}

DOI: https://doi.org/10.32782/2224-6282/157-3

Шиманська К. В.

доктор економічних наук, доцент, Державний університет «Житомирська політехніка» ORCID: https://orcid.org/0000-0003-0375-5102

Каленчук Л. В.

кандидат економічних наук, доцент, Державний університет «Житомирська політехніка» ORCID: https://orcid.org/0000-0002-6971-9553

Shymanska Kateryna, Kalenchuk Liudmyla Zhytomyr Polytechnic State University

\section{АНАЛІЗ СТАНУ ІНТЕРНАЦІОНАЛІЗАЦІЇ МАЛОГО ТА СЕРЕДНЬОГО БІЗНЕСУ УКРАЇНИ В УМОВАХ СВРОІНТЕГРАЦЇ̈}

\begin{abstract}
У статті проаналізовано значення інтернаціоналізачї малих та середніх підприємств для розвитку зовнішньоторговельної діяльності України в умовах європейської інтеграції. На основі статистичних даних проаналізовано динаміку долучення малих та середніх підприємств України та Житомирської області до зовнішньоторговельних операцій. Окреслено місие малого та середнього бізнесу у системі зовнішньоторговельних зв 'язків, який акумулює та використовує локальні ресурси, формуючи попит на внутрішньому ринку на робочу силу й ресурси. Описано внутрішні та зовнішні бар'єри інтернаціоналізащї малого та середнього бізнесу, зокрема відсутність доступу до фінансових ресурсів, неможливість отримання повної інформації про зарубіжний ринок, недостатність матеріальних та трудових ресурсів, мовні бар'єри персоналу малих та середніх підприємств. Сформульовано переваги та недоліки малих та середніх підприємств порівняно з великими компаніями за умов прямого виходу на ринок та ухвалення експортного рімення.
\end{abstract}

Ключові слова: міжнародна торгівля, малі та середні підприємства, інтернаціоналізачія бізнесу, експорт, вихід на зарубіжний ринок.

\section{ANALYSIS OF THE STATE OF SMALL AND MEDIUM-SIZED BUSINESS INTERNATIONALIZATION IN UKRAINE UNDER THE EUROPEAN INTEGRATION CONDITIONS}

Globalization and integration processes show positive trends in expanding access of small and medium enterprises to different forms of international cooperation, particularly in export and import operations. The article analyzes the importance of small and medium enterprises internationalization for the Ukraine's foreign trade development under the European integration conditions. Basing on statistical data, the dynamics of small and medium enterprises involvement in foreign trade operations was analyzed (at the national and Zhytomyr region levels). The place of small and medium business in the foreign trade relations system has been outlined. It covers local resources accumulation and use, forming the demand in the domestic market for labor and material resources. Internal and external barriers to the small and medium-sized businesses internationalization are described, including lack of access to financial resources, inability to obtain complete information about foreign markets, lack of material and labor resources, language barriers for SMEs'staff. The advantages and disadvantages of small and medium enterprises in comparison with large companies are formulated in terms of direct market entry and export decision-making. In the article it has been determined that small and medium enterprises of Ukraine and particularly Zhytomyr region have increased exports in recent years, their share in Ukraine's total exports is growing (especially for micro-enterprises). In addition, the volume of exports per enterprise is growing at the same time. In Zhytomyr region the corresponding growth trends of the SMEs' share in export activities should also be outlined, because it is higher than average indexes in Ukraine. Potentially, SMEs'development and internationalization will expand regional opportunities for effective employment; contribute to the households' incomes growth. National and regional disparities in SMEs'internationalization level should be equalized through the support of such enterprises, in particular by the regional development programs and the SMEs'expansion to European funding programs.

Keywords: international trade, small and medium enterprises, internationalization of business, export, entry into foreign market.

JEL classification: F15, F23, L25.

Постановка проблеми. Питання активізації зовнішньоекономічної діяльності означає для країни можливість більш повної реалізації власного природно-ресурсного та трудового потенціалу, здатність конкурувати та ефективно використовувати ресурси, отримувати від них більшу віддачу, диверсифікувати ризики нестабільності внутрішнього ринку. В умовах цифровізації економіки та інтелектуалізації праці розвиток зовнішньої торгівлі дає змогу країнам під- вищити рівень технологічного розвитку через обмін знаннями й трансфер технологій. Крім того, наявні тенденції посилення регіональної економічної інтеграції, зокрема долучення до євроінтеграційних процесів нашої держави, потенційно визначають ускладнення міжнародних економічних зв'язків, створення ефективних міжнародних виробничих ланцюгів. Проте важливе місце в цій системі зовнішньоторговельних зв'язків посідає малий та середній бізнес, який тільки 
акумулює та використовує локальні ресурси. У зв'язку 3 цим особливої актуальності набуває питання інтернаціоналізації діяльності малого та середнього бізнесу, зокрема в умовах євроінтеграційних трансформацій нашої держави.

Аналіз останніх досліджень і публікацій. Переважно проблематика наукових досліджень міжнародної торгівлі концентрується на питаннях впливу міжнародної торгівлі на національні економіки або економіку регіону, основних виграшах та втратах від активізації зовнішньої торгівлі та їі лібералізації (зокрема, доцільних методах та формах лібералізації). Останнім часом набуває актуальності питання значення регуляторної системи міжнародної торгівлі у дотриманні екологічних норм (особливо в умовах загострення екологічної кризи), а також «класично» важливе питання для міжнародних ринків продовольства, таке як вплив регулювання торгівлі сільськогосподарськими товарами для розвитку світової економіки. Значна група наукових досліджень присвячена глибокому аналізу та моделюванню торгової політики країн, іiї елементів та інструментів, впливу торгової політики на національну економіку, зокрема розробленню торгових політик в умовах інтеграційних процесів та торгових договорів.

Проте наше дослідження орієнтовано на питання, яке часто залишається осторонь сфери наукових інтересів, таке як значення інтернаціоналізації діяльності малого та середнього бізнесу в межах реалізації національної торговельної політики України в умовах іiї євроінтеграції. Зокрема, розвиток інтеграційних процесів у сфері міжнародної торгівлі, їх вплив на формування торговельної політики досліджували К. Аль-X'ярі (Khalil Al-Hyari), Г. Аль-Вешах (Ghazi Al-Weshah), М. Альнсур (Muhammed Alnsour) [5], Дж. Лов (J. Love), С. Ропер (S. Roper) [8], А. Лейпрас (A. Lejpras), Д. Беднарова (D. Bednáŕová), Й. Пражакова (J. Pražáková), П. Косiкова (Р. Kosíková), М. Хільмерсон (M. Hilmersson), М. Йохансон (M. Johanson) [4], А.Е. Гут'єрез Фернандес (A.E. Gutiérrez Fernández), M. Перез Суарез (M. Pérez Suárez) [3], Й. Чжоу (Y. Zhou) [7]. Наведені вчені виділили основні бар'єри виходу на ринок, зокрема для малого бізнесу.

Мета статті полягає в аналізі стану інтернаціоналізації малого та середнього бізнесу України в умовах євроінтеграції, окресленні ऑї значення для розвитку національної економіки та реалізації зовнішньоторговельної політики.

Виклад основного матеріалу. Глобалізація передбачає все ширше долучення країн до міжнародної торгівлі, що на рівні національної економіки реалізується через активізацію зовнішньоекономічної діяльності національних компаній, зокрема представників малого та середнього бізнесу.

«Однією з головних ознак ділового середовища двадцять першого століття $є$ феноменальне зростання глобалізації. Зіштовхнувшись 3 глобалізацією, країни інтенсивну політичну увагу приділяють інтернаціоналізації національних фірм. <..> Участь у міжнародному бізнесі стає особливо актуальною як 3 точки зору національного процвітання, так і для окремих організацій», - зазначають К. Аль-X'ярі (Khalil Al-Hyari), Г. Аль-Вешах (Ghazi Al-Weshah) та М. Альнсур (Muhammed Alnsour) [5], досліджуючи проблему бар'єрів інтернаціоналізації малих та середніх підпри- ємств у Йорданії. На важливості розвитку експортної конкурентоздатності компаній в умовах зростаючої глобалізації та зміцнення глобальних ланцюжків цінності наголошують Дж. Лов (J. Love) та C. Ропер (S. Roper) [8].

Під час виходу на зовнішні ринки визначальним аспектом $\epsilon$ спосіб, вибраний підприємством для виходу (прямі продажі, використання послуг посередника, робота $з$ торговельними мережами). А. Лейпрас (A. Lejpras) зазначає, що «інтернаціоналізація фірми функціонує лише шляхом експорту (активності та інтенсивності), хоча фірми можуть обрати багато інших режимів інтерналізації» [6]. Зазвичай така діяльність включає експортні та імпортні операції, проте вимагає на початку значних фінансових вкладень для забезпечення початку експорту.

В ході дослідження Дж. Лов та С. Ропер (2013 рік) доходять висновку, що «європейські малі та середні підприємства, які експортують, зростають більш ніж удвічі швидше, ніж ті, що не роблять, тоді як МСП, які працюють на міжнародному рівні, в три рази частіше впроваджують нові продукти в своєму секторі, ніж ті, які орієнтуються цілком на внутрішній ринок» [8].

Територіальна диверсифікація маркетингових зусиль підприємства, з одного боку, може знизити ризик відсутності очікуваних обсягів продажів, а з іншого боку, пов'язана зі значними витратами на освоєння ринку від подолання притаманних імпортних бар'єрів та забезпечення присутності підприємства, впізнавання бренду. До того ж українські реалії останніх років щодо зміни торговельних пріоритетів та посилення європейського вектору торговельної співпраці замість втрачених російських ринків свідчать про те, що малому та середньому бізнесу така переорієнтація відкриває ширші можливості для розвитку експортної діяльності в більш передбачуваному інституційному середовищі.

Якщо такі ринки є географічно близькими та економічно залежними (наприклад, ринки Східної Європи або загалом (С), оцінити ризики може бути складніше, адже на цих ринках діятимуть подібні фактори та загрози.

Багато в чому це залежить від переваг малих та середніх підприємств порівняно з великим бізнесом, проте вони мають свої недоліки. «До переваг, - як пишуть Д. Беднарова (D. Bednářová), Й. Пражакова (J. Pražáková) та П. Косікова (Р. Kosíková), - можна віднести гнучкість та швидке пристосування до вимог ринку, можливість створити діловий клімат регіону тощо. До недоліків можна віднести обмежені ресурси, як фінансові, так і трудові, труднощі в отриманні замовлень та доступ до нових ринків збуту» [1].

Однак позитивними трендами глобалізаційних та інтеграційних процесів $є$ те, що доступ до форм міжнародного співробітництва перестає слугувати виключно інтересам великих підприсмств, хоча очевидно, що майже всі етапи інтернаціоналізації бізнесу для них $€$ простішими як з організаційної, так і з фінансової точок зору. Натомість малі та середні підприємства мають обмежений доступ до інформаційних ресурсів, оскільки аналітичні огляди ринків, спеціалізовані для інформаційних запитів менеджменту таких підприємств, є досить дорогими, а прямі експортні зусилля часто можуть не дати очікуваного результату. До речі, слід вказати на існування досить банального, але серйозного бар'єра, а 
саме мовного бар'єра, тому під час оцінювання готовності малих та середніх підприємств до виходу на зарубіжний ринок важливим елементом самоаналізу стає аналіз готовності персоналу та менеджменту підприємства до роботи у мультикультурному середовищі.

Водночас ринкові ніші малих підприємств також суттєво відрізняються від ніш великого бізнесу, хоча вийти на локальні зарубіжні ринки вони здатні, пропонуючи через великі торговельні мережі якісний продукт для домогосподарств.

У науковій літературі пропонується вимірювати конкурентоспроможність експорту шістьма послідовними показниками, такими як розмір, співпраця, кількість цільових ринків, конкурентні переваги, роки діяльності та відсоток продажів за кордоном [3]. Додатково М. Хільмерсон (М. Hilmersson) та М. Йохансон (M. Johanson) (2016 рік) обгрунтовують тезу, що «швидкість інтернаціоналізації - це більш багатогранна та досконала концепція, ніж визнана сьогодні» [4].

«Експортна діяльність, - пишуть К. Аль-Х'ярі, Г. Аль-Вешах та М. Альнсур, - підвищує прибутковість, покращує баланс торгівлі та допомагає вирішувати проблеми бідності та безробіття. Малі фірми стають все більш міжнародними, і вони дають 25-35\% світового експорту. <...> Експорт - це найпоширеніший режим виходу на зовнішній ринок для цих фірм. Однак у країнах, що розвиваються, все ще багато МСП, які не експортують або навіть не думають про це, незважаючи на те, що експорт не потребує великих капітальних вкладень та має менший фінансовий та комерційний ризик порівняно з прямими інвестиціями» [5]. Враховуючи викладене вище, маємо оцінити показники значення підприємств малого та середнього бізнесу в українському та регіональному експорті (на прикладі Житомирського регіону).
На основі офіційно оприлюднених даних Державної служби статистики України нами проаналізовано обсяги інтернаціоналізації малого та середнього бізнесу протягом 2015-2018 років за такими показниками:

- кількість суб'єктів господарювання (за показниками кількості працівників як одного з критеріїв класифікації підприємств згідно з Господарським кодексом України), од.;

- частка суб'єктів відповідного розміру у загальній кількості експортерів, \%;

- обсяги експорту суб'єктів відповідного розміру, млн. дол. США;

- частка обсягів експорту суб'єктів відповідного розміру у загальному обсязі експорту, \%;

- обсяг доходів від на 1 суб'єкта відповідного розміру, млн. дол. США.

Результати аналізу даних представлено у табл. 1.

Представлена у табл. 1 динаміка свідчить про посилення значення малого та середнього бізнесу у розвитку експорто орієнтованої стратегії нашої держави. Зауважимо, що в середньому приріст обсягу доходів на одного суб'єкта зовнішньоекономічної діяльності становить 98,4\% для мікропідприємств, 8,3\% - для малих, $20,1 \%$ - для середніх.

Засловами А.Е.Гут'єреза Фернандеса(А.E. Gutiérrez Fernández) та M. Перез Суарез (M. Pérez Suárez), «підприємства збільшують своє проникнення на зовнішні ринки, коли їх конкурентна перевага більша, ніж у конкурентів, тому вимірювання конкурентоспроможності $€$ постійним пріоритетним завданням на макро- та мікроекономічному рівнях» [3]. Саме варіація показників приросту загального обсягу експорту й цих категорій підприємств (від $-24,9 \%$ для мікропідприємств до $+16,8 \%$ для середніх підприємств) вказує на різний рівень конкурентоспроможності, адже на ринку зали-

Таблиця 1

Аналіз зміни кількості підприємств-експортерів України та обсягів їх експорту (за їх розмірами) у 2015-2018 роках

\begin{tabular}{|c|c|c|c|c|c|}
\hline \multirow[b]{2}{*}{ Показник } & \multicolumn{5}{|c|}{ Підприємства за розмірами (за критерієм кількості працівників) } \\
\hline & $\begin{array}{c}\text { мікро- } \\
\text { (до } 9 \text { осіб) }\end{array}$ & $\begin{array}{c}\text { малі } \\
\text { (10-49 осіб) }\end{array}$ & $\begin{array}{c}\text { середні } \\
(50-249 \\
\text { осіб) }\end{array}$ & $\begin{array}{c}\text { великі } \\
\text { (250 осіб } \\
\text { і більше) }\end{array}$ & ФОП \\
\hline \multicolumn{6}{|c|}{ Усього по Україні (2015 рік) } \\
\hline Кількість суб’єктів, од. & 5086 & 4259 & 2897 & 1245 & 5002 \\
\hline Частка у загальній кількості експортерів, \% & 25,8 & 21,6 & 14,7 & 6,3 & 25,4 \\
\hline Обсяги експорту, млн. дол. США & 1728,1 & 2930,1 & 6060,2 & 25815,3 & 314 \\
\hline Частка у загальному обсязі експорту, \% & 4,53 & 7,69 & 15,89 & 67,71 & 0,82 \\
\hline $\begin{array}{l}\text { Обсяг доходів на } 1 \text { суб’єкта, } \\
\text { млн. дол. США }\end{array}$ & 0,340 & 0,688 & 2,092 & 20,735 & 0,063 \\
\hline \multicolumn{6}{|c|}{ Усього по Україні (2018 рік) } \\
\hline Кількість суб’єктів, од. & 1926 & 3544 & 2818 & 1198 & 6353 \\
\hline Приріст з 2015 року, \% & $-62,1$ & $-16,8$ & $-2,7$ & $-3,8$ & 27,0 \\
\hline Частка у загальній кількості експортерів, \% & 8,4 & 15,4 & 12,2 & 5,2 & 27,6 \\
\hline Зміна питомої ваги з 2015 року, \% & $-17,5$ & $-6,2$ & $-2,5$ & $-1,1$ & 2,2 \\
\hline Обсяги експорту, млн. дол. США & 1298,4 & 2639,4 & 7080,5 & 32031,6 & 337,1 \\
\hline Приріст з 2015 року, \% & $-24,9$ & $-9,9$ & 16,8 & 24,1 & 7,4 \\
\hline Частка у загальному обсязі експорту, \% & 2,7 & 5,6 & 15,0 & 67,7 & 0,7 \\
\hline Зміна питомої ваги з 2015 року, \% & $-1,8$ & $-2,11$ & $-0,94$ & $-0,04$ & $-0,11$ \\
\hline Обсяг доходів від експорту на 1 суб’єкта & 0,674 & 0,745 & 2,513 & 26,738 & 0,053 \\
\hline Приріст з 2015 року, \% & 98,4 & 8,3 & 20,1 & 28,9 & $-15,5$ \\
\hline
\end{tabular}

Джерело: складено та розраховано за даними Державної служби статистики [13-16] 
шаються підприємства, здатні конкурувати та нарощувати індивідуальні обсяги експорту.

Загалом аналогічні тенденції спостерігаються за більш детального розгляду динаміки обсягів експорту підприємств (за їх розмірами) Житомирської області (табл. 2).

Як бачимо, регіональні показники мають ще більші диспропорції, але на рівні Житомирської області приріст обсягу доходів на одне мікропідприємство зріс за досліджуваний період на $175,4 \%$, тоді як відповідний показник зменшився по середніх підприємствах на $8,2 \%$.

К. Аль-Х'ярі, Г. Аль-Вешах та М. Альнсур відзначають, що багато ризиків інтернаціоналізації генеровані самою глобалізацією: «навіть у розвинених країнах мало МСП намагалися побудувати конкурентоспроможний експорт без державної підтримки; отже, політичні заходи повинні бути спрямовані на зменшення бар'єрів для входу на ринок та зниження витрат на міжнародне розширення, наприклад, захист прав власності і трансакційних витрат» [5].

Дж. Лов, С. Ропер та Й. Чжоу вважають, що «заходи щодо сприяння доступу до фінансів також відіграють важливу роль за рахунок збільшення ліквідності МСП та грошових потоків, залишаючи більше можливостей для інвестицій в інновації та розвиток експорту. Вони найбільш цінні, коли супроводжуються консультаціями спеціалістів чи наставництвом» [7].

Отже, вважаємо, що національні та регіональні особливості й диспропорції у рівні інтернаціоналізації мають вирівнюватися за рахунок підтримки підприємств малого та середнього бізнесу. Проте для подальшої інтернаціоналізації їх діяльності та посилення значення зовнішньоекономічної діяльності регіону слід запроваджувати програми регіонального розвитку, створювати інституційні умови для розширення можливостей регіональних МСП до програм європейського фінансування.

Висновки. За результатами дослідження сформульовано такі висновки.

1. Інтернаціоналізація діяльності малих та середніх підприємств є невід'ємним елементом розбудови зовнішньоекономічної діяльності України, адже потенціал цих підприємств є значним і з точки зору можливості диверсифікації експорту, і з точки зору можливості вирішення локальних проблем регіонів через активізацію їх діяльності. Зокрема, йдеться про зростання зайнятості у регіонах саме на підприємствах малого та середнього бізнесу, що означає потенційне підвищення рівня життя населення, зростання фіскальних надходжень.

2. Доступ до форм міжнародного співробітництва стає частиною реальності функціонування малого та середнього бізнесу України. Проте МСП мають обмежений доступ до ресурсів, зокрема інформаційних та фінансових, що стає ризик-фактором їх успішної діяльності на зарубіжному ринку, тому оцінювання фінансової, організаційної та кадрової готовності малих та середніх підприємств до виходу на зарубіжний ринок $\epsilon$ важливим елементом самоаналізу перед початком активної інтернаціоналізації.

3. Іншим аспектом є зміцнення товарних брендів України саме шляхом забезпечення високого рівня якості товарів національних виробників, зокрема малого та середнього бізнесу. Це вимагає розбудови програм підтримки таких суб'єктів як на державному, так і на місцевому рівнях, долучення їх до програм просування експорту, зокрема навчальних програм для представників МСП.

Таблиця 2

Аналіз зміни кількості підприємств-експортерів Житомирської області та обсягів їх експорту (за їх розмірами) у 2015-2018 роках

\begin{tabular}{|c|c|c|c|c|c|}
\hline \multirow[b]{2}{*}{ Показник } & \multicolumn{5}{|c|}{ Підприсмства за розмірами (за критерієм кількості працівників) } \\
\hline & $\begin{array}{l}\text { мікро- } \\
\text { (до } 9 \text { осіб) }\end{array}$ & $\begin{array}{c}\text { малі } \\
(10-49 \text { осіб) }\end{array}$ & $\begin{array}{c}\text { середні } \\
\text { (50-249 осіб) }\end{array}$ & $\begin{array}{c}\text { великі } \\
\text { (250 осіб } \\
\text { і більше) }\end{array}$ & ФОП \\
\hline \multicolumn{6}{|c|}{ Усього по Житомирській області (2015 рік) } \\
\hline Кількість суб'єктів, од. & 168 & 168 & 90 & 55 & 43 \\
\hline Частка у загальній кількості експортерів, \% & 30,1 & 30,1 & 16,1 & 9,8 & 7,7 \\
\hline Обсяги експорту, млн. дол. США & 43,5 & 47,1 & 115,9 & 352,4 & 30,5 \\
\hline Частка у загальному обсязі експорту, \% & 9,86 & 10,67 & 26,26 & 79,85 & 6,91 \\
\hline $\begin{array}{l}\text { Обсяг доходів від експорту на } 1 \text { суб’єкта, } \\
\text { млн. дол. США }\end{array}$ & 0,259 & 0,280 & 1,288 & 6,407 & 0,709 \\
\hline \multicolumn{6}{|c|}{ Усього по Житомирській області (2018 рік) } \\
\hline Кількість суб’єктів, од. & 61 & 130 & 98 & 56 & 730 \\
\hline Приріст з 2015 року, \% & $-63,7$ & $-22,6$ & 8,9 & 1,8 & 1597,7 \\
\hline Частка у загальній кількості експортерів, \% & 4,5 & 9,7 & 7,3 & 4,2 & 54,2 \\
\hline Зміна питомої ваги з 2015 року, \% & $-25,5$ & $-20,4$ & $-8,8$ & $-5,7$ & 46,5 \\
\hline Обсяги експорту, млн. дол. США & 43,5 & 47,1 & 115,9 & 352,4 & 30,5 \\
\hline Приріст з 2015 року, \% & 0,0 & 0,0 & 0,0 & 0,0 & 0,0 \\
\hline Частка у загальному обсязі експорту & 6,6 & 7,1 & 17,5 & 53,2 & 4,6 \\
\hline Зміна питомої ваги з 2015 року, \% & $-3,3$ & $-3,56$ & $-8,75$ & $-26,61$ & $-2,30$ \\
\hline Обсяг доходів від експорту на 1 суб'єкта & 0,713 & 0,362 & 1,183 & 6,293 & 0,042 \\
\hline Приріст з 2015 року, \% & 175,4 & 29,2 & $-8,2$ & $-1,8$ & $-94,1$ \\
\hline
\end{tabular}

Джерело: складено та розраховано за даними Державної служби статистики [13-16] 


\section{Список використаних джерел:}

1. Bednářová D., Pražáková J., Kosíková, P. Cooperation and Entry of SMEs into Foreign Markets. In Scientific Conference INPROFORUM, 2016.

2. Francioni B., Pagano A., Castellani D. Drivers of SMEs' exporting activity: a review and a research agenda. Multinational Business Review. 2016. № 24 (3). P. 194-215. URL: http://centaur.reading.ac.uk/66857 (дата звернення: 17.07.2020).

3. Gutiérrez Fernández A.E., Pérez Suárez M. The export competitiveness of social enterprises as compared to with export SMEs, 2017.

4. Hilmersson M., Johanson M. Speed of SME internationalization and performance. Management International Review. 2016. № 56 (1). P. 67-94.

5. Al-Hyari Kh., Al-Weshah Gh., Alnsour M. Barriers to internationalisation in SMEs: evidence from Jordan. Marketing Intelligence \& Planning. 2012. Vol. 30. Issue 2. P. 188-211.

6. Lejpras A. Determinants of export performance: differences between service and manufacturing SMEs. Service Business. 2019. № 13 (1). P. 171-198.

7. Love J.H., Roper S., Zhou Y. Experience, age and exporting performance in UK SMEs. International Business Review. 2016. № 25 (4). P. 806-819.

8. Love J., Roper S. SME innovation, exporting and growth. Enterprise Research Centre. White Paper. 2013.

9. OECD, "Top Barriers and Drivers to SME Internationalisation", Report by the OECD Working Party on SMEs and Entrepreneurship, OECD, 2009.

10. Pickernell D., Jones P., Thompson P., \& Packham G. Determinants of SME exporting: Insights and implications. The International Journal of Entrepreneurship and Innovation. 2016. № 17 (1). P. 31-42.

11. Rahman M., Uddin M., Lodorfos G. Barriers to Enter into Foreign Markets: Evidence from SMEs in emerging market. International Marketing Review. 2017. № 34 (1). P. 68-86.

12. Sozinova A.A., Fokina O.V., Shchinova R.A. Marketing tools for increasing company's reorganization effectiveness. Overcoming Uncertainty of Institutional Environment as a Tool of Global Crisis Management. Springer. Cham, 2017. P. 315-320.

13. Експорт товарів суб'єктами господарювання за кількістю найманих працівників за видами економічної діяльності у 2018 році / Державна служба статистики України. URL: http://ukrstat.gov.ua/operativ/operativ2018/zd/et_knp_reg/arh_et_knp_u.html (дата звернення: 10.07.2020).

14. Експорт товарів за кількістю найманих працівників у розрізі регіонів у 2015 році / Державна служба статистики України. URL: http://ukrstat.gov.ua/operativ/menu/menu u/zed.htm (дата звернення: 10.07.2020).

15. Експорт товарів суб'єктами господарювання за кількістю найманих працівників у розрізі регіонів у 2018 році / Державна служба статистики України. URL: http://ukrstat.gov.ua/operativ/operativ2018/zd/et_knp_reg/arh_et_knp_reg_u.html (дата звернення: 10.07.2020).

16. Експорт товарів за кількістю найманих працівників за видами економічної діяльності у 2015 році / Державна служба статистики України. URL: http://www.ukrstat.gov.ua/operativ/operativ2018/zd/et_knp_reg/arh_et_knp_u.html (дата звернення: 10.07.2020).

\section{References:}

1. Bednářová D., Pražáková J., Kosíková P. (2016) Cooperation and Entry of SMEs into Foreign Markets. Scientific Conference INPROFORUM, p. 63.

2. Francioni B., Pagano A., Castellani D. (2016) Drivers of SMEs' exporting activity: a review and a research agenda. Multinational Business Review, 24 (3), pp. 194-215.

3. Gutiérrez Fernández A.E., Pérez Suárez M. (2017) The export competitiveness of social enterprises as compared to with export SMEs. Revista Galega de Economia, vol. 26-1, pp. 55-72.

4. Hilmersson M., Johanson M. (2016) Speed of SME internationalization and performance. Management International Review, 56 (1), pp. 67-94.

5. Khalil Al-Hyari, Ghazi Al-Weshah, Muhammed Alnsour (2012) Barriers to internationalisation in SMEs: evidence from Jordan. Marketing Intelligence \& Planning, vol. 30, iss. 2, pp. 188-211.

6. Lejpras A. (2019) Determinants of export performance: differences between service and manufacturing SMEs. Service Business, 13 (1), pp. 171-198.

7. Love J.H., Roper S., Zhou Y. (2016) Experience, age and exporting performance in UK SMEs. International Business Review, 25 (4), pp. 806-819.

8. Love J., Roper S. (2013) SME innovation, exporting and growth. Enterprise Research Centre. White Paper, (5).

9. OECD (2009) Top Barriers and Drivers to SME Internationalisation. Report by the OECD Working Party on SMEs and Entrepreneurship.

10. Pickernell D., Jones P., Thompson P., Packham G. (2016) Determinants of SME exporting: Insights and implications. The International Journal of Entrepreneurship and Innovation, 17 (1), pp. 31-42.

11. Rahman M., Uddin M., Lodorfos G. (2017) Barriers to Enter into Foreign Markets: Evidence from SMEs in emerging market. International Marketing Review, 34 (1), pp. 68-86.

12. Sozinova A.A., Fokina O.V., Shchinova R.A. (2017) Marketing tools for increasing company's reorganization effectiveness. In Overcoming Uncertainty of Institutional Environment as a Tool of Global Crisis Management, pp. 315-320.

13. Derzhavna sluzhba statystyky Ukrainy (2019) Eksport tovariv sub'jektamy ghospodarjuvannja za kiljkistju najmanykh pracivnykiv za vydamy ekonomichnoji dijaljnosti u 2018 roci [Exports of goods by economic entities by number of employees by type of economic activity in 2018]. Available at: http://ukrstat.gov.ua/operativ/operativ2018/zd/et_knp_reg/arh_et_knp_u.html (accessed 10 July 2020).

14. Derzhavna sluzhba statystyky Ukrainy (2016) Eksport tovariv za kiljkistju najmanykh pracivnykiv u rozrizi reghioniv $u$ 2015 roci [Exports of goods by economic entities by number of employees by type of economic activity in 2015]. Available at: http://ukrstat.gov.ua/operativ/menu/menu u/zed.htm (accessed 10 July 2020).

15. Derzhavna sluzhba statystyky Ukrainy (2019) Eksport tovariv sub’jektamy ghospodarjuvannja za kiljkistju najmanykh pracivnykiv u rozrizi reghioniv u 2018 roci [Exports of goods by economic entities by the number of smaller employees by region in 2018]. Available at: http://ukrstat.gov.ua/operativ/operativ2018/zd/et_knp_reg/arh_et_knp_reg_u.html (accessed 10 July 2020)

16. Derzhavna sluzhba statystyky Ukrainy (2016) Eksport tovariv za kiljkistju najmanykh pracivnykiv za vydamy ekonomichnoji dijaljnosti u 2015 roci [Exports of goods by economic entities by the number of smaller employees by region in 2015]. Available at: http://www.ukrstat.gov.ua/operativ/operativ2018/zd/et_knp_reg/arh_et_knp_u.html (accessed 10 July 2020) 